Pace University

DigitalCommons@Pace

Faculty Working Papers

Lubin School of Business

6-5-2018

The new financial framework for the Cuban non-state sector

Pavel Vidal

P.V. Viswanath

Follow this and additional works at: https://digitalcommons.pace.edu/lubinfaculty_workingpapers

Part of the Finance and Financial Management Commons, International Business Commons, and the International Economics Commons 


\title{
Microfinance Cuban Style: \\ The new financial framework for the Cuban non-state sector
}

\author{
February 2017
}

\section{Pavel Vidal \\ Economics Department, Pontificia Universidad Javeriana Cali, Valle del Cauca, Colombia}

\author{
and \\ P. V. Viswanath \\ Lubin School of Business, Pace University, New York, NY, USA
}

This is an original manuscript / preprint of an article published by Taylor \& Francis in Post-Communist Economies on $5^{\text {th }}$ June 2018, available online: https://www.tandfonline.com/doi/abs/10.1080/14631377.2018.1460534

\begin{abstract}
The Cuban economic system and, along with it, the Cuban financial system has been changing since the coming to power of Raul Castro. In this paper, we analyze some of the changes in the Cuban financial system and the goals of the government in implementing these changes. Using the results of a survey of non-state businesses, we look at the microfinance sector - the provision of financial services to the small and medium enterprises in the non-state sector - from two perspectives: first, the nature of the new credit regulations and bank policies and how they accomplish the evaluation of credit to a hitherto non-existent sector; and second, how do these small business clients view their relationship with their lender state banks. We look at Cuban finance from the perspective of a socialist economy in transition and compare it to microfinance elsewhere, particularly in China and India.
\end{abstract}

Keywords: Cuba, Private Sector, Reform, Banks, Microfinances

JEL: G21, G28, L26, M13, P34 


\section{Introduction}

Cuba has been changing gradually but systematically ever since 2008 when Raul Castro became president. A cornerstone of the current Cuban economic model reforms is its openings to the non-state small scale sector: self-employed individuals (cuentapropistas), SMEs, individual farmers and cooperatives. Cuban reforms combine a shrinking of the state sector, expecting an increase in productivity and public salaries, with an expansion of the non-state sector. In November 2011, a new program was announced opening credit to the emerging self-employed and SME sector. The government outlined a legal framework to expand microloans from state banks.

On December 2014, the US announced policy changes toward Cuba. Although it does not completely removed the embargo against the island, the flexibility measures promoted by President Obama have had a positive impact on tourism, remittances and investment interest. The White House said that one of the principal objectives of its new policy would be promoting the expansion of the private sector in the island. For this it drew up a list of products and services that the Cuban private sector could export to the United States. In addition, the U.S. government has been studying the mechanisms to allow the sale of construction materials, inputs and equipment for private businesses and farmers. It also announced that it would authorize projects for the development of microfinance in Cuba. With the coming in of the new US administration, there will probably be somewhat of a cooling towards Cuba, but it is unlikely that all the Obama administrations actions will be overturned.

In this context, our paper examines the new financial framework for microfinance in Cuba and the attitudes of the Cuban non-state sector to it. The empirical assessments are based on a survey sent out to self-employed individuals, SMEs, individual farmers, and cooperatives. The survey, which is a first in Cuba, consists of 21 questions conducted on a sample of 120 businesses in two Cuban provinces (Havana and Matanzas) in 2015.1 The sample is relatively small but informative and valuable since there are no other similar academic studies based on actual data on the private sector and microfinance in Cuba. The survey results allow us to analyze for the first time, the factors affecting the demand for banking services by the Cuban non-state sector. 2

Although there is no clear sign, as yet, that the Cuban government is open to cooperation and international investment in the field of microfinance, the Cuban government could eventually consider an invitation to international players in this sector as part of the economic reform and rapprochement with the U.S. This paper discusses the characteristics and peculiarities of the microenterprise market in Cuba that would help in designing future strategies of collaboration and investment in this sector. In this respect, it would be useful to compare microfinance developments in Cuba with developments in that sector in other countries with a view to obtaining insights as to where the new regulations in Cuba might need. For this purpose, we look in particular at China and India: China, because of similarities in terms of the state orientation; and India, because of the important role assigned to the state banking sector.

$\mathbf{1}$ The text of the questionnaire is provided in Appendix A. The survey was implemented with the help of the Centro Cristiano de Reflexión y Diálogo (Matanzas) and Acción Internacional (Bogotá).

$\mathbf{2}$ For a comprehensive qualitative analysis of the Cuban private sector, see Ritter and Henken (2014) and Mesa-Lago et al (2016). 
The paper is structured as follows. Section 2 looks at the proposed regulations for the Cuban microfinance sector in the allocation of credit for the emerging non-state sector, from the point of view of an economy in transition. Section 3 briefly compares microfinance in Cuba with microfinance in China and India. Section 4 describes and analyzes the characteristics of the proposed regulations for the new microfinance sector. Section 5 presents the results of our survey of non-state businesses, including their relationship to the Cuban financial system. Section 6 provides a brief evaluation of the current system and speculates regarding future prospects. Section 7 concludes.

\section{The Cuban non-state sector and the banking sector in an economy in transition}

One must keep in mind that the Cuban state is still directed by the Communist Party of Cuba and by Raul Castro, in his capacity as the President of Cuba, but also as the First Secretary of the Communist Party of Cuba. As such we have to relate the development and organization of the non-state sector with respect to the possible goals and objectives of the Communist Party. A prime tenet of Cuban socialism is the ownership of the means of production and the primacy of the state sector. The problem with such a strong reliance on the state sector is that without the financial support first of the Soviet Union, and thereafter of Venezuela, the lack of incentives that has been the Achilles heel of socialist state-led economies has choked off any possible growth in the Cuban economy (Vidal, 2015). The Cuban government, through the state sector, has not been able to satisfy the aspirations of the Cuban people. It is a commonplace in Cuba that the monthly state salaries are sufficient only to support a family for fifteen days. Consequently, the system needs private enterprise to supply food and various other services to the Cubans. Given the socialist orientation of the state, it is not possible to move entirely to a capitalist market-based system. In other words, at least for the present, the non-state sector is still seen as a safety-valve for the shortcomings of the state sector.

Pleskovic (1994) provides an interesting analysis of the financial systems of eastern European economies in transition in the early nineties. The objective at that time was for most of those economies to move slowly to a capitalistic, market-driven system. Pleskovic (1994) lays down four planks for the overhaul of the financial systems of those economies: demonopolization of banking, improvement of the system of payments, change in the structure of ownership (including privatization) and the introduction of market-based financial legislation.

There is movement in Cuba on all these fronts - for example, starting from a single monobank, there now are nine state-owned commercial banks, 15 non-banking financial institutions, 3 eleven offices representing foreign banks and 4 representative offices of non-banking financial institutions. Foreign financial institution have no branches on the island; they only have a license to represent their bank in connection with operations within the Cuban economy. Although the single monobank has been broken up into several state banks, there is no real competition between them; rather, they are specialized according to market segment and the currencies they use within the Cuban dual monetary system. Some are focused on external trade operations, and loans and deposits in convertible pesos (CUC) and foreign exchange. Others are more related to personal banking, and operations with agriculture and domestic industries using the two national currencies in circulation, the CUC and the Cuban peso (CUP) (See Vidal and Pérez,

3 Non-banking financial institutions operate without banking windows. They don't work with individuals, only with enterprises and state organizations. 
2014). This is very similar to the system that developed in the late 1990s in Eastern Europe - a true demonopolization of the banking sector will have to wait for a while.

A variety of payment methods are available to non-state actors, though all settlement is ultimately done through the central bank. In addition to cash, the following payment instruments are available: bank transfers, checks, debit cards, local letters of credit, bills of exchange and promissory notes. The financial system has achieved a certain progress in modernization, computerization and development of new services since the 1990s, but is yet far from achieving the necessary capabilities. The technological lag is evident in the non-use of either online banking services, mobile banking services or credit cards. Furthermore, an important part of the financial service industry is concentrated in Havana and the country's provincial capitals, making access to financial services difficult in most of the country. For example, currently there are only 498 ATMs, of which 343 are in Havana. Until the beginning of 2014, about 1.6 million debit cards had been issued, of which 1.2 million in Havana. This represents only $31.5 \%$ of the economically active population.

\section{Table 1: Two Banking System indicators (2013)}

The number of bank branches per 100,000 adults is not far from the Latin America average. But Cuba lags behind regarding ATMs quantity. Table 1 presents both indicators considering some smaller countries in the region. According to information published by the National Bureau of Statistics, the ratio of deposits to GDP was 24\% in 2013. Figure 1 compares this the situation in other countries in the region. As can be seen, Cuba is in a group with lower financial deepening, together with Dominican Republic and Mexico.

Figure 1: Financial Deepening (Deposits / GDP), Year 2013

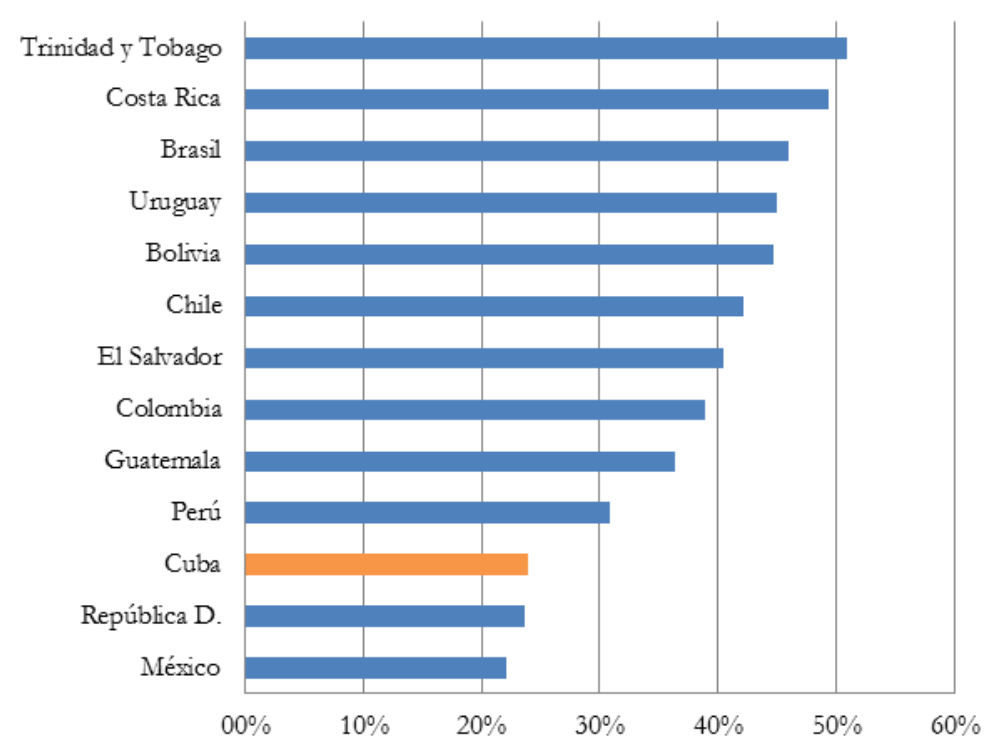

Source: Authors' calculations based on data from International Monetary Fund and ONEI (various years)

It is in the changes with respect to the structure of ownership and market-based financial innovation that there is the greatest cause for hope. While privatization of the state sector is unlikely to occur as far as most sectors are concerned, the government recognizes that the provision of consumer goods and particularly of services by the state sector has been insufficient and inefficient. The result has been a shrinking of the state 
sector and a corresponding expansion of the non-state sector, though the government is trying to keep the pace of the two processes comparable, in order to avoid unemployment. From 2009 to 2014, state employment was reduced by 663,700 workers, while the non-state sector grew by 561,000. Self-employment and SMEs created 339,600 new job posts, and the cooperatives and farmers increased by 221,500 workers. At present the non-state sector is responsible for $28 \%$ of total employment. Until 2012 it presented a rather robust growth, though this has slowed down, of late (ONEI, various years).

Although the Cuban government has authorized 201 different types of activities, the largest activities developed by self-employment and SMEs in Cuba are restaurants and cafeterias, covering $13 \%$ of the licenses granted; transportation services account for $10 \%$, while renting houses and rooms account for another $7 \%$. There is also demographic diversity within the non-state sector; official figures show that $70 \%$ of persons involved in this sector are male, $12 \%$ seniors (over 60 years), 19\% had a college degree, and 17\% kept a job in the state sector. Havana, Matanzas, Villa Clara, Camagüey, Holguín and Santiago de Cuba provinces together account for $66 \%$ of all private workers in the country. 4

Private farmers and agricultural cooperatives are also part of the non-state sector; in fact, they were never eradicated from the Cuban countryside even during the revolutionary process in the 1960s. Diverse forms of agricultural cooperatives coexisted with individual farmers. Farmers and agricultural cooperatives, in fact, have always remained linked to banks through savings accounts, checking accounts and different types of loans. This would be the segment with the greatest financial literacy within the Cuban non-state sector. Since 2010, private and agricultural cooperatives have grown more rapidly as a result of the policy of distribution of idle land, given in usufruct. About 187,000 individuals have benefited under this policy (Nova, 2013).

The Cuban reform gives greater priority to cooperatives over private enterprises. The reason is that cooperatives are considered to provide for a more equitable distribution of wealth; as such, they are considered to promote principles more "correlated" with socialism. A new legal framework was established on December 11 to promote nonagricultural cooperatives. So far, 498 non-agricultural cooperatives have been accredited, of which 173 are located in Havana. Around $80 \%$ of the new cooperatives were created from existing state enterprises units. Most are engaged on foodstuff business (42\%), followed in importance by retail services (20\%) and construction (13.7\%). Other less common activities are manufacturing, recycling, and transportation, among others (Piñeiro, 2012).

There are many obstacles that have been suggested as weighing down the sector: the absence of a wholesale market, the high price of inputs, restrictions on imports, difficulties in gaining access to financing, the dual currency, a limited list of allowed activities, little space for the participation of professionals, who could provide services with a greater added value and high taxes. An illegal input market is the only alternative to this that the self-employed and micro-entrepreneurs have to ensure their survival (Ritter and Henken, 2014; Mesa-Lago et al, 2016). Self-employed persons and SMEs must pay three basic taxes: a personal income tax - a progressive scale is applied, ranging from

\footnotetext{
4 See http://www.cubadebate.cu/etiqueta/trabajo-por-cuenta-propia/
} 
$15 \%$ to $50 \%$; a sales tax of $10 \%$ applied on gross sales revenue; and a workforce tax, which is $5 \%$ of the payroll and is intended to discourage the concentration of wealth in the private sector. They also contribute to social security (Pons, 2016).

\section{3: Cuban Microfinance: How Idiosyncratic is it?}

Until recently, Cuban banks mainly provided loans to state enterprises and agricultural cooperatives (particularly the Unidades Básicas de Producción Cooperativas (UBPC) which have very limited autonomy). Self-employed persons and private farmers were essentially shut out of the credit market. In addition, private businesses were severely restricted in terms of access to bank instruments of payment and current accounts; for the most part, they were required to use cash for their commercial operations.

In November 2011, new steps were announced opening credit to the emerging selfemployed and SME sector. The government outlined a legal banking framework aimed at expanding credit and financial services to individuals, private businesses and cooperatives. Three state banks, Banco Metropolitano, Banco de Crédito y Comercio (BANDEC) and Banco Popular de Ahorro (BPA), are in charge of the new loans and financial services. The credit amounts are small (a few hundred dollars, on average) and borrowers must still provide unconventional collateral, which may take the form of banking deposits, promissory notes guaranteed by a financial institution, personal property and certain kinds of real estate but not the permanent house of the borrower. Interest rates are relatively low - from $4.25 \%$ to $9 \%$ - relative to what is common in the microfinance sector globally, but it must be kept in mind that these bank loans in Cuba require collateral and hence default risk is also low.

In the three years since the policy was introduced, 378,011 persons had obtained financing worth 135 million USD at the current exchange rate (as of October 2014). Of these loans, $63 \%$ (US\$85 million) has been provided to finance construction activities in family homes. Part of these credits contribute to new businesses, as well, since some of this construction is intended for the purpose of renting rooms to tourists and leasing spaces to restaurants (paladares) or cafeterias. The second largest chunk of these loans $(34 \%)$ has gone to individual farmers. Self-employed persons, and micro- and smallenterprises received just $2.6 \%$ of the new loans. Consumer goods loans constituted only $0.3 \%$ out of the total. 5

We will now take a look at the strategy of using banks to finance microenterprises. Since the spread of microfinance in modern times, it is special microfinance institutions (MFIs) that have been used to finance microenterprises all over the world, rather than banks. The reasons for this are various; however, an important reason is the small size of the transactions and the resulting high relative cost of doing due diligence on borrowers and on monitoring loans. The situation in Cuba is somewhat different. While the average size of the enterprises is still small, the objective of the government is somewhat different from that in Bangladesh, India, Indonesia, Mexico, and the various other countries where microfinance has prospered. In those countries, microenterprise and microfinance were seen as a way of reducing poverty; as such, governments were interested in increasing the size of the sector and expanding it to the poorest of the poor. In Cuba, however, the

5 Unfortunately, no information is available on the amount of credit provided in total by the banking sector. 
government, while interested in promoting the non-state sector, is not interested in seeing it mushroom and expand at the cost of the state sector. This history of state involvement might suggest a parallel with China, another communist country.

State influence in Chinese microfinance can be seen everywhere, even in the most basic details of the operation of MFIs. For example, a hallmark of the early Grameen Bank strategy, $\mathbf{6}$ to compensate for the lack of proper institutional and economic structures, was to create five-person groups that would constitute the borrowing unit. In China, however, "both rural and urban areas were already organized into hierarchical units under the central government. People were not used to working outside of these groups. Therefore, microfinance institutions had to create groups that more closely resembled existing organizations. In some villages for instance, there were compulsory weekly meetings for almost the entire populations. These replaced smaller leadership meetings that were seen as central to microfinance's success elsewhere."7 Contrary to the existence of informal and private institutions elsewhere in the world, China did not allow non-financial institutions to offer financial services to the public; furthermore, all institutions operating in this sphere were dependent on the government. For example, rural credit cooperatives were established as early as the 1980s, but they were run very inefficiently and even after being overhauled in the 1990s, local government interference was a drag on their operations and on access to funding.

More recently in 2008, after the enactment of special regulations on the operation of microloan companies, a host of state-owned institutions - city commercial banks, newlycommercialized rural credit cooperatives and others under the supervision of the China Banking Regulatory Commission (CBRC) entered the fray (Cousin, 2011; chapter 7). These institutions, however, generally make individual loans and require collateral, as a rule. Land is the most valuable asset in rural areas and lack of ownership title to the land means that farmers cannot provide collateral to access these loans. Hence, while serving rural areas, they do not serve the traditional microfinance population. The CBRC has approved formal rural community-based mutual aid funds that provide savings and credit services to their members. There are also quasi-formal mutual aid funds that are loosely regulated by the local People's Bank of China (the Chinese central bank) office and based on voluntary capital contributions by their members. Because these are grass root organizations, there is less information asymmetry than in the formal mutual aid funds, which means better supervision of loans and also the possibility of collateral-free loans. In 2006, the central government under the auspices of the Ministry of Finance provided credit funds with the explicit objective of poverty alleviation. Finally, there are informal, unregulated cooperative mutual fund groups that provide small, collateral-free loans (Ong and $\mathrm{He}, 2014)$.

We see in China that the state has simultaneously discouraged the role of private, independent microfinance organizations while at the same time - though with varying degrees of success -- providing funding for state-sponsored or state-supervised and preferably cooperative credit organizations. Microfinance in Cuba, currently, is restricted

\footnotetext{
6 Grameen Bank was started in 1983 by Professor Muhammad Yunus in Bangladesh. Prof. Yunus was one of the pioneers of modern microfinance who, as early as 1976, worked on the delivery of an efficient credit delivery system to provide banking services to the rural poor.

7 Clydesdale and Shah (2016) http://asiasociety.org/education/microfinance-china-micro-vsmandarin, viewed October $6^{\text {th }}, 2016$.
} 
to three state banks. It is unlikely that the government will relinquish control over access to credit, and hence the restriction of microfinance to state banks is likely to continue. On the other hand, Cubans already have access to a fairly important source of capital, viz. remittances from friends and relatives abroad, primarily in the US. In fact, $13.3 \%$ of the respondents in the microenterprise survey described in section 5, depended on remittances as a source of capital for their business. What this means is that, one the one hand, a complete state monopoly on sources of capital is not possible; on the other, there is less of an impetus for the development of state-controlled credit cooperatives with popular participation, as in China. This explains the mix of state and private channeling of finances to non-state businesses.

As long as the supply of credit by state banks is low relative to the demand, the quality of the loans provided can be kept high. This is also aided by the requirement of collateral. This mitigates the problems caused by the lack of incentives and decentralization of lending authority in state banks. However, as the private sector continues to develop and this is not at all unlikely, considering the shortages of essential goods (vegetables, fruits, dairy goods) and services in the economy, lending by state banks on such conditions, is likely to fall short. Looking to the experience of India in the 1970s and 1980 s, such lending by state banks is likely to become unprofitable, as well as insufficient. Lending on collateral is also likely to restrict the advantages of access to credit to already privileged individuals and likely to increase wealth inequality. If access to credit becomes more egalitarian, then one possible solution to solving problems of capital sources as well as income inequality is to develop credit cooperatives that are regulated, but only lightly controlled by the government.

Microfinance has been prevalent in India since the 1970s and it currently has the largest number of active borrowers, about 39.5 million in 2014. 8 Most microloans in India are funded by bank debt; however, banks do not lend all of this money directly to borrowers. They either lend to self-help groups (SHGs) or to microfinance institutions (MFIs) that then turn around and lend the funds to SHGs or to joint liability groups (JLGs). A JLG is a group of four to ten individuals that come together in order to borrow from an MFI either individually or as a group using a framework of joint liability, where each member of the JLG is liable for all loans made to anybody in the group. An SHG, on the other hand, is a kind of cooperative, which borrows from an MFI or a bank and then lends these funds to individuals in the SHG. In 2013-14, 240.17 billion Rs. were lent to SHGs (Manohar, 2015). In March 2010, 58.77\% of the total amount of microloans outstanding had been disbursed through SHGs (Champatiray et al. 2010), indicating the relative importance of SHGs.

In 1992, the National Bank for Agriculture and Rural Development (NABARD) developed the first SHG-Bank Linkage Program (SBLP). The model operates in three forms: in the first model, banks themselves promote SHGs and extend credit to its members as a group; in the second model, SHGs are promoted by government or NGOs, but are directly financed by the banks; in the third model, SHGs are promoted by other agencies such as MFIs and loans are given by the banks to these other agencies. In 2006, about $20 \%$ of loans were disbursed under the first model, $70 \%$ used the second model and only $10 \%$ or so were made under the third model. In other words, roughly half of the

8 http://www.economist.com/news/international/21708258-microlending-booming-once-againif-it-help-people-out-poverty-though-it 
funds disbursed as microloans were made by banks directly to SHGs. Such a two-tier structure consisting of state-owned banks lending to borrower-run SHGs is thus, another model for Cuba that would allow the government to maintain control of the deployment of financial resources.

As noted earlier, the model currently in use in Cuba is for banks to lend directly to individuals. In China, we saw that banks have played an important part in making collateralized microloans, while government- and self-financed cooperatives make collateral-free loans. In India, we see a merging of these two models in the SBLP program with banks lending to SHGs. Given the socialist characteristic of Cuba, it is possible that an expansion of microlending would lead to a Chinese type cooperative credit society model; on the other hand, a SBLP-type model could be more attractive, given the relative importance of self-employed private businesses versus cooperatives in Cuba. Adoption of this model would probably require a greater amount of economic liberalization. Which of these two models Cuba adopts as microlending grows probably depends on political developments in Cuba.

As long as banks are entrusted with the provision of credit, however, the success of the microlending program and its ability to function as a stimulant to the economy will depend on how efficient they are in their resource allocation.

\section{Loan terms and regulation}

In this section, we will first discuss the terms of the loan contracts, as envisaged by the new legal framework for microfinance operations in Cuba since $2011^{9}$ and then look at the regulatory environment for the banks involved.

\section{Loan terms}

Although it would be appropriate to call the loans microloans from the point of view of their size and their developmental purpose, most of the characteristics of microloans that one may be familiar with from other countries are missing in the Cuban version. In particular, there is no exploitation of social capital in any form to control information asymmetry; rather, Cuban microloans look very similar to their larger counterparts in many ways, particularly in terms of their reliance on collateral, as we shall see.

First of all, the amounts that are available for borrowing are quite generous. In other parts of the world, micro-lenders have been criticized for restricting the size of their loans so that borrowers are not able to make optimal use of the funds for investment. In addition to the size of the loans, the requirement that repayment start almost immediately, along with the relatively short duration of most loans, limits the utility of the loans. Under the new legal framework, self-employed individuals and SMEs can borrow from a minimum of 3,000 Cuban pesos (U\$125 at current exchange rate in exchange houses) for working capital for terms not exceeding eighteen months, and for investments up to five years. Loans for building and construction materials or for financing the cost of construction labor can be granted in amount of 1,000 Cuban pesos upwards (U\$2). Legally, there is no maximum limit for any of the loans. The amount and loan term is agreed between the parties according to the activity to be financed and the proposed guarantees within defined parameters.

\footnotetext{
9 See Ministerio de Justicia (2011).
} 
Most MFI loans elsewhere in the world are provided for working capital purposes - if not expressly, then in practice - since loan instalment payments start almost immediately. In contrast, the new microloans in Cuba can be made for investment purposes: the loan duration of five years in this case is unheard of with most microloans. On the other hand, it must be acknowledged that the maturity and size restrictions placed on microloans in other environments is primarily because of the lack of collateral. For example, the requirement that repayment began immediately self-selects for borrowers who have access to other sources of capital. Cuban microloans, on the other hand, come with collateral requirements. Financial instruments such as bills of exchange or promissory notes guaranteed by a financial institution or bank deposits and third party savings accounts can be used as collateral. $\mathbf{1 0}$ Since such assets could be used directly to finance working capital or other investment, it is primarily the two other forms of collateral that contribute to the availability of larger and more flexible loans, viz. personal property and salaries or incomes. Houses, however, cannot be offered as collateral. While somewhat paternalistic, this is to ensure that nobody loses his primary residence; in that sense, this is similar to the homestead exemptions in several US states that protect home equity from creditors in bankruptcy.

For private farmers, loan minimums are 500 Cuban pesos (U\$21). Such loans are available for working capital in the sowing season and crops harvesting; for livestock (cattle acquisition expenditures and herd attention); and for inputs purchase and investments in facilities and necessary maintenance, land use and development of permanent crops. The main guarantee is the value of the output to be obtained or, in case of blight or other infestation, the compensation paid by the mandatory insurance policy.

In addition, applicants for loans must complete a form where feasibility, revenues, potential market and business guarantees are estimated. Also to be submitted to the bank are the copy of the license of the business and the proof of the last tax payment (in the case of an already existing business). The banking Credit Committee at the branch, provincial or central level, has the ability to approve within a pre-specified range that depends on the requested amount. The ready availability of such formal documents also contrasts with the informal environment in which microloans are made elsewhere. The sort of vetting that is possible in Cuba, thus, greatly reduces the risk to the bank. On the other hand, banks are unlikely to have much expertise in assessing market sales; it is, therefore, yet to be seen, as to how successful Cuban banks will be in keeping the risk of these microloans manageable.

In order to compensate banks for any risk that they might be exposed to, the prescribed interest rates include risk premiums. Interest rates are set by adding a margin, approved by the Central Bank, to the interest rates on fixed term savings deposits. The annual interest rates for a fixed term account is ranging from $4 \%$ p.a. for one year period to $6.50 \%$ p.a. for a three years deposit. Approved margins depend on the loan purpose and have a range within which banks can move according to undertaken risk assessments. Therefore, the highest annual interest rate would be for an investment of three years: $9 \%$ p.a. in the event the bank considered it at higher risk. The lowest annual interest rate would be for one-year loan for purchasing building and construction materials: $4.25 \%$ p.a. For persons

10 In fact, it is mandatory for anyone with an annual gross income exceeding 50,000 Cuban pesos or its equivalent in convertible pesos (U\$2,083) to have a bank account. 
with a legal right to use the land (usufruct), the minimum interest rate for working capital and investment is applied during the first two years of operation, so it would be $4.5 \%$ p.a.

After three years of bank credit opening with private businesses the achieved results are not overwhelming but not disappointing. Official figures showed that after three years of the new policy 378,011 natural persons had received financing, worth 135 million US dollars to the current exchange rate. This works out to an average of about $\$ 357$ per person.

\section{Regulatory Framework}

Many countries have seen their microfinance sectors collapse, starting with Bolivia in the 1980s and Andhra Pradesh in 2008; the main problem has been unfettered competition and lack of debtor information leading to excess competition and over-indebtedness. One of the strengths of the Cuban system is that the banks making the loans are state-owned and under central bank superintendence and supervision, reducing the risk of borrower over-indebtedness and portfolio mismanagement. The Cuban Central Bank Division of Superintendence has issued five regulations to support the new financial policy. It has also set out a preliminary credit scoring system based on international practices. Commercial banks also must meet certain standards of banking supervision regulations, like minimum capital requirements, risk concentration, and provision policy as recommended by the Basel I accords (Banco Central de Cuba, 2011).

The next section will present the results of our survey of non-state businesses. We describe the characteristics of these businesses, their financing patterns and their views of the banking system.

\section{Cuban microenterprise and the Cuban financial system}

\section{Business enterprise characteristics}

The vast majority of enterprises in our sample were owned by individuals (66.7\%), while $22.5 \%$ of the business were family-owned; only $3.2 \%$ were cooperatives. As far as business type, the largest group was private restaurants (19\%) and cafeterias (16\%), reflecting the reality that a lot of businesses have moved into the gastronomic field. The rental housing, transportation, agriculture and barbershops all together, accounted for $17 \%$, all of them more or less equal in importance. The remaining $48 \%$ is dedicated to different sorts of activities, most of them involving low value-added service activities, and few of them related to professional services. $\mathbf{1 1}$

11 Appendix B lists some of the alternative responses that were given in answer to this question. 
The businesses in our sample have been operating for about 4 years and one month on average, with cafeterias and agricultural business being a lot older, while hairdressers, restaurants and transportation businesses were the most recent. 12 On the other hand, they do differ greatly in terms of the number of employees, whether they tend to hire family members, their self-characterization of success and the initial capital invested. Agricultural businesses, transportation businesses and restaurants tended to require the most capital and also to have the most employees; they also tended to be most likely to hire non-family employees. Agricultural businesses were least likely to report that they were successful, there was not much difference on this score between the other business types.

\section{Financing}

Another measure of business size concerns the initial capital amount. Out of the total, $46.85 \%$ indicated they started their business with less than $300 \mathrm{CUC}$ (equivalent to 300 USD); $70.27 \%$ of respondents indicated that they had started the business with the equivalent of less than 1000 USD; and only 7 business $(6.31 \%)$ replied that they had begun with capital exceeding U\$ 10,000, of which 5 are restaurants (paladares), the other two being a children's recreation business and an agriculture-related business. Details regarding these characteristics, by type of business can be found in Table 2 below. For many families these ventures are a survival strategy, $36 \%$ of respondents specified that business revenues represent $100 \%$ of family income, $16 \%$ indicated that represented three-quarters and, $18 \%$ said half.

\section{Table 2: Characteristics of businesses}

We next look at the sentiments of the business owners regarding various barriers to running their businesses successfully. We asked respondents to choose up to three different barrier (details in Table 3). The lack of required inputs is considered the biggest barrier to growth, with $71.7 \%$ of businesses considering it important. 13 The other two barriers following in importance are high taxes (45.8\%) and excessive regulation (39.2\%), signaling tax policy and institutional weaknesses as the two other factors constraining non-state business expansion on the island. Lack of funding was marked by only $16.7 \%$ of respondents; i.e. compared to other barriers, the lack of funding is not perceived by entrepreneurs today, among the main obstacles to their development. We did conjecture that lack of funding might be considered an important barrier to growth for businesses that might require greater capital investment, such as businesses in the restaurant and transportation sectors. However, the difference in initial capital between those who chose lack of funding as a barrier to growth and those who didn't was statistically insignificant $(\mathrm{t}=0.599)$.

Most of the seven business types that we identify in our survey follow the pattern established above, with lack of inputs being the most frequent grouse, followed by high

12 Two responses that identified their business type as a restaurant also indicated other affiliated businesses, one rental housing and the other a cafeteria. They have both been classified as a restaurant alone for the analysis in Table 1, on the presumption that that is their primary business involvement.

13 Many respondents indicated more precisely that there was a lack of wholesale markets where they could buy their inputs; others indicated that they were shut out of state-owned enterprises that sold products they needed because they were self-employed. 
taxes and excessive regulation. For transportation businesses, however, lack of funding is quite important as well, with two out of the five transportation businesses citing it. Still, lack of funding is far less important than the bureaucratic problems created by too much government interference. This may, however, change over time, as the government becomes more responsive and reduces its interference.

\section{Table 3: Perceived Barriers to Business Growth, by Business Type}

We now look at the relationship of our businesses with the banking sector. In keeping with what we reported above regarding the relative unimportance of financing as a business barrier, only $7.5 \%$ of our respondents (i.e. only 9 out of the 120 surveyed businesses) reported that they had applied for a bank loan during the past three years. When asked why respondents had not applied, the most common answers were "Prefer not getting into debt" (45.0\%) and "Do not need it because I have the necessary capital" $(40.5 \%)$. Other reasons were also identified, but with lower percentages (see Table 4).

\section{Table 4. Reasons given for not applying for a bank loan}

Again, consistent with the lack of importance assigned by respondents to financing difficulties, we found that most business owners had obtained financing on their own ( $80 \%$, see Table 5), while only $1.7 \%$ used a bank loan. As noted above in the previous section, it is likely that a large proportion of borrowers under the new regime have been farmers. Since only $6 \%$ of our sample consists of agricultural businesses, it is not surprising that most of our respondents have not applied for a bank loan. It is also noteworthy that only $13.3 \%$ of businesses said they had remittances as funding source, which contradicts a widespread approach that identifies it as the main financing source for private businesses in Cuba. Loans from friends and family, together, represented an interesting $28.4 \%$ of responses. Some of this might well be from family members abroad, which, if true, would increase the amount obtained from remittances. On the other hand, this could be evidence of an informal, local financial market. However, the responses do not allow us to determine how organized this market might be.

\section{Table 5. Sources of capital/financing}

\section{Relations with Banks}

To examine in more detail, the question of how our respondents relate to the banking system, we asked a series of questions. Only $35 \%$ of respondents noted that they had a bank account, while $61.7 \%$ did not (3.3\% did not respond). Of those that did have a bank account, most made monthly or yearly deposits ( $9.2 \%$ and $10 \%$, respectively), which is much less frequently than depositors would interact with their banks is most countries where the banks are a key component of the financial system. This is also reflected in the fact that $43.3 \%$ of respondents indicated that they held their savings outside the banking system. In fact, when we asked respondents how important banks were for their business, $38 \%$ said that they did not use banks at all, and another $28 \%$ considered them to be of little importance; only $19 \%$ said that banks were very important, while $12 \%$ said they were fairly important. Notwithstanding the relative unimportance ascribed by respondents to banks, more than a third do have a bank account; this suggests that there is no issue of mistrust of the banking system; most likely, it is the lack of convenience and financial return that leads our respondents to use banks as sparingly as they do 
We next look at respondents' attitudes toward the banking sector by business type (Table 6). Some businesses that are more service sector- oriented with frequent cashflows (restaurants, cafeterias and hairdressers) might find banking services more necessary. Alternatively, it is possible, as we suggested above, that sectors that require a greater capital investment (restaurants, transportation and agriculture) might find banks more useful. We find that some attitudes of respondents did vary by business type. For example, we were able to definitively reject the hypothesis that possession of a bank account or frequency of saving is unrelated to business type. In fact, we found that businesses that had high initial capital requirements or were service establishments were more likely to have a bank account $(\mathrm{t}=2.36$ and $\mathrm{t}=3.59$ respectively. Further, we also found that business that had high initial capital requirements tended to rate banking services as more important $(\mathrm{t}=1.96)$; however, there was no difference in this respect between service-oriented businesses and others $(\mathrm{t}=-1.36)$. We were also able to reject the hypotheses that businesses requiring more initial capital were more likely to apply for a bank loan $(\mathrm{t}=1.11)$.

\section{Table 6. Attitudes towards banks by business type}

\section{How banking service users differ from non-users}

We now look at how businesses that have a bank account differ from those that don't, as well as how businesses that have applied for bank credit differ from those that have not (Table 7). The test results indicate that neither age nor sex nor the race of entrepreneurs is associated with the demand for banking services. Compared to businesses that don't have a bank account, businesses having a bank account tend to have more employees, employees who are not relatives, consider banking services to be more important, make more frequent deposits, believe themselves to be more successful and have had business training.

Compared to businesses that have not applied for bank credit, those that have applied for bank credit tend to have more employees, consider banks more important, believe business insurance to be useful, run businesses that contribute a higher share of total family income, and seek consulting advice. Interestingly enough, businesses that have a bank account tend to reinvest their business surplus in the business less frequently; this may be due to the greater availability of business credit from banks. On the other hand, businesses that had applied for a bank loan did not seem to have a statistically significantly lower tendency to reinvest profits in the business.

\section{Table 7. Possession of bank account/Application for bank credit and Business Characteristics}

\section{Evaluation and prospects for the future}

The bank-led model used in Cuba for microfinance has the advantage of providing economies of scale and thus, to reduce, the cost of the provision of microcredit. However, the lack of previous experience could also lead to unforeseen outcomes.

Along with the provision of microcredit, banks could also expand into the provision of micro financial services, such as savings accounts, payment services, facilitation of remittances and other services. Taxes could be paid through banks, as also social security contributions, payments for electric services, telephone, gas, water etcetera. These banking services also have the effect of reducing the need for cash working capital, thus 
decreasing operational costs for micro-entrepreneurs and farmers. Another strength of the Cuban microfinance system is that illiteracy and the problem with personal IDs is not a problem as in some Latin American countries. Safe transportation to and from poor rural areas is also an advantage, in contrast to the high risk of theft and robbery suffered by MFIs in some African and Latin American countries.

On the other hand, financial literacy is still low. In addition, the dual monetary system and restrictions on trade and commerce are obstacles with regards to business access to imports and key inputs. Although using the existing state-owned banking system can be an advantage in terms of scale economies, there is a risk that microfinance will end up being highly subsidized and unsustainable. It is known that operational costs for this kind of institution are extremely high because of the existing interpersonal clients/institutions model. These costs are often not reflected in interest rates because rates are controlled by the central bank and fixed at extremely low values, compared to international standards. Thus, there are two possible scenarios. One, loans could negatively impact the bank's profitability thus requiring subsidies (explicit or implicit) from the Cuban financial system. Two, once the demand for loans grows, banks could end up setting barriers and bureaucratic obstacles, thus limiting the funding of otherwise viable and profitable projects.

Finally, state banks are not promoting partnerships with other stakeholders in the expansion of expand microcredit. International experience shows how essential is the construction of strategic partnerships that include municipal governments, regional enterprises, NGOs, and universities and research centers that could act as microenterprise incubators. Local institutions contribute to the choice of the best projects, help identify local financial needs and facilitate the development of "tailored" microfinance services.

\section{Conclusions}

State banks have begun to pave the way for microfinance in Cuba. Unfortunately, state banks have very little experience in this market segment and have not entered into partnerships with other stakeholders. In addition, the low level at which the central bank has set interest rates raises the possibility that it is unsustainable. The lack of experience with information and communications technologies also represents a hindrance.

In the medium term, if the Cuban government decides to invite international cooperation and investment in this sector, it will be necessary to re-examine the legal and economic framework in order to design the most appropriate structure. Foreign partners will also need to think of how best to respond to the Cuban government. This study offers an analysis of market characteristics and the peculiarities of Cuban microenterprises that would help in designing strategy.

Currently, most businesses in the so-called non-state sector classify as microenterprises given their size. The average number of employees per business according to our survey was 4 with a median number of two and a maximum of 35 . Of the surveyed businesses, three-quarters said that they had started their business with less than U\$2,000. These put them squarely in the microenterprise category. As we have noted, the average loan size to date over the three years that the new policy has been in effect is $\$ 357$. This suggests that those businessmen who have applied for loans have been in the lower end of the spectrum. If the policy is successful, this suggests that the average loan size is likely to 
rise, with a corresponding rise in the risk to the banks' portfolios. In addition, businessmen from other sectors may be expected to apply for loans, as well. These businessmen are likely to be in more consumer-responsive industries; if so, banks might need expertise that they currently lack. Furthermore, they will also need more accountants and market analysts, all of which is likely to be quite challenging for banks.

Eighty percent of our respondents indicated that they had started their business with their own capital and many of these indicated that they had not applied for bank loans because they did not want to be indebted. On the other hand, these may well be the low-hanging fruit, viz. the initial wave of non-state enterprises who have their own sources of financing. If the market economy grows and the tolerance of the state for private enterprise grows, there is likely to be a larger role for microfinance. The eagerness to start new businesses may also be inferred from the fact that while only a fifth of our respondents had had business training, two-thirds were interested in obtaining business advice.

Another surprising result was that only about an eighth of our respondents indicated using remittances to finance their businesses. There is no reason to believe that this is likely to increase, since remittances have been feasible now for many years. On the other hand, any Cuban-Americans wanting to invest in Cuba have had to do it, anonymously, through Cuban relatives. If rules on American direct investment in Cuba and transacting with the Cuban government is relaxed, there may well be a greater flow of FDI into Cuba.

Finally, we make recommendations regarding the structure of Cuban microfinance. Our comparative analysis of Cuban microfinance on the one hand and Indian and Chinese microfinance, on the other, suggests that Cuba may want to consider the development of a two-tier structure consisting of state-owned banks lending to borrower-run SHGs or credit cooperatives. This would reduce the onus on the banks to conduct a credit analysis as to engage in the monitoring of borrowers and would certainly be useful until the Cuban government develops specialized financial institutions that would cater to microfinance clients. 


\section{References}

Banco Central de Cuba. 2011. Resolución No. 112 y 113. Instrucción No. 6, 9, 11 and 12. Circular No. 1 and 4, Havana.

Champatiray, Amulya Krishna; Parul Agarwal and Santadarshan Sadhu. 2010. "Map of Microfinance Distribution in India," IFMR.

Clydesdale, Heather and Kajal Shah. 2016. "Microfinance in China: Micro vs. Mandarin," http://asiasociety.org/education/microfinance-china-micro-vsmandarin,

Cousin, Violaine. 2011. Banking in China. Palgrave-McMillan.

Manohar, Louis. 2015. "Growth of SHG-Bank Linkage Programme - A Comparative Study of Six Regions in India," International Journal of Research in Humanities and Social Studies Volume 2, Issue 8, August 2015, pp. 28-37.

Mesa-Lago, C., R. Veiga, L. González, S. Vera, A. Pérez-Liñán. 2016. Voces de cambio en el sector no estatal cubano. Madrid Editorial Iberoamericana.

Ministerio de Justicia. 2011. Gaceta Oficial No. 040 Extraordinaria, November.

Nova, Armando. 2013. "Sector Agropecuario y Lineamientos". Handbook of Contemporary Cuba: Economy, Politics, Civil Society, and Globalization, 2013, p. 81, Paradigm Publisher, London.

Oficina Nacional de Estadísticas e Información de Cuba (ONEI). Various years. Anuario Estadístico de Cuba. Havana

Ong, Lynette and Guangwen He. 2014. "Chinese Rural Cooperative Finance in the Era of Post-Commercialized Rural Credit Cooperatives," The Chinese Economy, v. 47, no. 4, July-August, pp. 81-98.

Piñeiro, Camila (ed.). 2012. Cooperatives and Socialism: A view from Cuba. Springer.

Pleskovic, Boris. 1994. Financial policies in socialist countries in transition. Policy, Research working paper ; no. WPS 1242. Washington, DC: World Bank. http://documents.worldbank.org/curated/en/225151468763171083/Financialpolicies-in-socialist-countries-in-transition

Pons, Saira. 2016. "Balance de cuatro años de reformas en el sistema tributario cubano." Cuban Studies 44.

Ritter, A. and T. Henken. 2014. Entrepreneurial Cuba: the changing policy landscape. Lynne Rienner.

Vidal, P., and O. Pérez. 2014. "Monetary reform in Cuba leading to 2016: Between graduation and the big bang", in Feinberg, R., Piccone, T. (Eds.), Cuba's Economic Change in Comparative Perspective, Brookings Institution, Washington, D.C, pp.85-102.

Vidal, P., 2015. "Cuba's reform and economic growth: A comparative perspective with Vietnam", Journal of Economic Policy Reform 19(2), 1-18. 
Table 1: Two Banking System indicators (2013)

\begin{tabular}{|lll|}
\hline País & $\begin{array}{l}\text { Bank branches per } \\
\mathbf{1 0 0 , 0 0 0} \text { adults }\end{array}$ & $\begin{array}{l}\text { ATMs per 100,000 } \\
\text { adults }\end{array}$ \\
\hline Cuba & 11.1 & 7.3 \\
Costa Rica & 22.3 & 71.4 \\
Uruguay & 12.7 & 45.2 \\
Dominican Republic & 11.7 & 33.1 \\
Latin America & 14.5 & 35.6 \\
\hline
\end{tabular}

Source: Authors' calculations based on data from International Monetary Fund and Banco Central de Cuba 
Table 2: Characteristics of businesses

\begin{tabular}{|c|c|c|c|c|c|c|}
\hline $\begin{array}{l}\text { Business Type } \\
\text { (number of obs in } \\
\text { parentheses) }\end{array}$ & $\begin{array}{l}\text { Percent } \\
\text { of total } \\
\text { sample }\end{array}$ & $\begin{array}{l}\text { Age of } \\
\text { business } \\
\text { (in mths) }\end{array}$ & $\begin{array}{l}\text { No. of } \\
\text { employee } \\
\text { s } \\
\end{array}$ & $\begin{array}{l}\text { Type } \\
\text { empl } \\
\text { (0=relat, } \\
\text { 1=other) }\end{array}$ & $\begin{array}{l}\text { Self-eval } \\
\text { re success } \\
3=v \text { succ, } \\
2=\text { satisfac } \\
, 1=a v \\
\text { succ, } \\
0=\text { unsucc }\end{array}$ & $\begin{array}{l}\text { Initial } \\
\text { Capital } \\
\text { (USD) }\end{array}$ \\
\hline Restaurant (23) & $19.17 \%$ & 23.61 & 7.783 & 0.870 & 1.783 & 3933.33 \\
\hline Cafeteria (19) & $15.83 \%$ & 80.63 & 2.632 & 0.684 & 1.421 & 982.35 \\
\hline Rental Housing (5) & $4.17 \%$ & 42 & 0.400 & 0.400 & 1.600 & 800.00 \\
\hline Transportation (5) & $4.17 \%$ & 22.8 & 8.000 & 0.800 & 1.800 & 3825.00 \\
\hline Agriculture (6) & $5.00 \%$ & 118.17 & 10.000 & 0.833 & 1.000 & 3266.67 \\
\hline Hairdressing (4) & $3.33 \%$ & 11.75 & 2.000 & 0.500 & 2.250 & 612.50 \\
\hline Other (58) & $48.33 \%$ & 47.70 & 1.621 & 0.362 & 1.552 & 815.45 \\
\hline Average & & 49.053 & 3.608 & 0.558 & 1.583 & 1663.96 \\
\hline $\begin{array}{l}\text { Test for equality of } \\
\text { means across } \\
\text { business types }\end{array}$ & & $\begin{array}{r}\text { Prob }>F= \\
0.0204\end{array}$ & $\begin{array}{r}\text { Prob }>F \\
=0.0000\end{array}$ & $\begin{array}{r}\text { Prob }>F= \\
0.0005\end{array}$ & $\begin{array}{r}\text { Prob }>F \\
=0.0802\end{array}$ & $\begin{array}{r}\text { Prob }>F= \\
0.0002\end{array}$ \\
\hline
\end{tabular}


Table 3: Perceived Barriers to Business Growth, by Business Type

\begin{tabular}{|crrrrrrrrr|}
\hline $\begin{array}{l}\text { Bus type/ } \\
\text { Barrier type }\end{array}$ & $\begin{array}{l}\text { None } \\
\text { lack } \\
\text { of } \\
\text { inputs }\end{array}$ & $\begin{array}{l}\text { lack of } \\
\text { funding }\end{array}$ & $\begin{array}{l}\text { lack of } \\
\text { demand }\end{array}$ & $\begin{array}{l}\text { high } \\
\text { taxes }\end{array}$ & $\begin{array}{l}\text { excessive } \\
\text { regulation }\end{array}$ & Other \\
\hline Restaurant & 0 & 20 & 3 & 1 & 12 & 11 & 3 & 4 \\
\hline Cafeteria & 0 & 18 & 3 & 3 & 12 & 10 & 3 & 2 \\
\hline Rental Housing & 0 & 3 & 0 & 0 & 3 & 2 & 1 & 0 \\
\hline Transportation & 0 & 4 & 2 & 0 & 5 & 2 & 1 & 0 \\
\hline Agriculture & 0 & 4 & 1 & 1 & 0 & 2 & 0 & 2 \\
\hline Hairdressing & 0 & 3 & 0 & 0 & 2 & 2 & 1 & 1 \\
\hline Other & 5 & 34 & 11 & 11 & 21 & 18 & 13 & 8 \\
\hline $\begin{array}{l}\text { Percentage of } \\
\text { businesses }\end{array}$ & $4.2 \%$ & $71.7 \%$ & $16.7 \%$ & $13.3 \%$ & $45.8 \%$ & $39.2 \%$ & $18.3 \%$ & $14.2 \%$ \\
\hline Total & 5 & 86 & 20 & 16 & 55 & 47 & 22 & 17 \\
\hline
\end{tabular}


Table 4. Reasons given for not applying for a bank loan

a) I do not need it because I have the necessary capital

b) The maximum loan amount granted by banks is not enough $11.7 \%$

c) Don't know the procedures to apply

d) Prefer not getting into debt

$41.7 \%$

e) I do not want to show my balances

$6.7 \%$

f) I find it very troublesome

$15.0 \%$

g) Other

$8.3 \%$

No reply

$9.2 \%$

Source: Authors' calculations 
Table 5. Sources of capital/financing

\begin{tabular}{|ll|}
\hline & \\
a) Own savings & $80.8 \%$ \\
b) Remittances & $13.3 \%$ \\
c) Bank loan & $1.7 \%$ \\
d) Friend loan & $9.2 \%$ \\
e) Family loan & $19.2 \%$ \\
f) The business is shared with someone not living in Cuba & $3.3 \%$ \\
g) Other & $2.5 \%$ \\
No reply & $0.00 \%$ \\
\hline
\end{tabular}

Source: Authors' calculations 
Table 6. Attitudes towards banks by business type

\begin{tabular}{|c|c|c|c|c|c|}
\hline Business Type & $\begin{array}{l}\text { Did you } \\
\text { Apply for } \\
\text { Bank } \\
\text { Credit in } \\
\text { last three } \\
\text { years? } \\
\text { (\% saying } \\
\text { yes) }\end{array}$ & $\begin{array}{l}\text { How imp } \\
\text { are banks } \\
\text { to you? } \\
\text { 3=v. imp, } \\
2=\text { fairly; } \\
\text { 1=not imp; } \\
\text { 0=don't } \\
\text { bank }\end{array}$ & $\begin{array}{l}\text { Do you } \\
\text { have a } \\
\text { bank } \\
\text { savings } \\
\text { a/c? } \\
\text { (\% saying } \\
\text { yes) }\end{array}$ & $\begin{array}{l}\text { How freq do } \\
\text { you save in } \\
\text { a bank? } \\
\text { 4=weekly, } \\
\text { 3=monthly, } \\
2=\text { =quarterly, } \\
\text { 1=annual }\end{array}$ & $\begin{array}{l}\text { Do you } \\
\text { save other } \\
\text { than in } \\
\text { banks? } \\
\text { (\% saying } \\
\text { yes) }\end{array}$ \\
\hline Restaurant (23) & $4.3 \%$ & 1.087 & $73.9 \%$ & 1.13 & $34.8 \%$ \\
\hline Cafeteria (19) & $0.0 \%$ & 0.895 & $21.1 \%$ & 0.842 & $36.8 \%$ \\
\hline $\begin{array}{l}\text { Rental Housing } \\
\text { (5) }\end{array}$ & $0.0 \%$ & 0.800 & $20.0 \%$ & 0.4 & $0.0 \%$ \\
\hline Transportation (5) & $40.0 \%$ & 1.600 & $20.0 \%$ & 0 & $60.0 \%$ \\
\hline Agriculture(6) & $16.7 \%$ & 2.500 & $33.3 \%$ & 1.333 & $33.3 \%$ \\
\hline Hairdressing (4) & $0.0 \%$ & 0.000 & $25.0 \%$ & 0.75 & $25.0 \%$ \\
\hline Other (58) & $8.6 \%$ & 1.069 & $27.6 \%$ & 0.586 & $53.4 \%$ \\
\hline Average & $7.5 \%$ & 1.092 & $35 \%$ & 0.741 & $43.33 \%$ \\
\hline $\begin{array}{l}\text { Test for equality } \\
\text { of means across } \\
\text { business types }\end{array}$ & $\begin{array}{l}\text { Prob }>F= \\
0.0853\end{array}$ & $\begin{array}{l}\text { Prob }>F= \\
0.0183\end{array}$ & $\begin{array}{l}\text { Prob }>F= \\
0.0024\end{array}$ & $\begin{array}{l}\text { Prob }>F= \\
0.4695\end{array}$ & $\begin{array}{l}\text { Prob }>F= \\
0.1999\end{array}$ \\
\hline $\begin{array}{l}\text { Service businesses } \\
\text { more positive } \\
\text { towards banks? }\end{array}$ & No, $t=-1.75$ & No, $\mathrm{t}=-1.36$ & Yes, $\mathrm{t}=3.59$ & No, $t=1.51$ & No, $t=-1.50$ \\
\hline $\begin{array}{l}\text { Bus with higher } \\
\text { init cap more } \\
\text { positive to banks? }\end{array}$ & No, $t=1.11$ & Yes, $t=1.96$ & Yes, $\mathrm{t}=2.36$ & No, $t=1.31$ & No, $t=-0.70$ \\
\hline
\end{tabular}


Table 7. Possession of bank account/Application for bank credit and Business Characteristics

\begin{tabular}{|lcccc|}
\hline & \multicolumn{2}{c}{$\begin{array}{c}\text { Having or not a bank } \\
\text { account }\end{array}$} & \multicolumn{2}{c|}{$\begin{array}{c}\text { Applied for bank } \\
\text { credit }\end{array}$} \\
\hline & Yes & No & Yes & No \\
\hline Gender of respondent & 0.622 & 0.688 & 0.625 & 0.667 \\
\hline Age of respondent & 40.382 & 43.129 & 40.857 & 42.258 \\
\hline Race of respondent & 0.914 & 0.895 & 1.000 & 0.895 \\
\hline Age of business & 58.225 & 44.027 & 40.286 & 49.632 \\
\hline No of employees & 6.119 & $2.256^{* *}$ & 6.667 & $3.360^{*}$ \\
\hline Type of employee (0=relat, 1=other) & 0.714 & $0.474^{* *}$ & 0.667 & 0.550 \\
\hline Applied for bank credit (Yes=1) & 0.095 & 0.064 & 1.000 & 0.000 \\
\hline $\begin{array}{l}\text { Imp of banks (3=v. imp, 2=fairly; } 1=\text { not } \\
\text { imp; 0=don't bank) }\end{array}$ & 1.405 & $0.923^{* *}$ & 2.778 & $0.955^{* *}$ \\
\hline Has savings account (1=yes, 0=no) & 1.000 & 0.000 & 0.444 & 0.342 \\
\hline Frequency of deposits & 2.048 & $0.038^{* *}$ & 0.778 & 0.739 \\
\hline Saves outside banking sys (1=yes, 0=no) & 0.405 & 0.449 & 0.333 & 0.441 \\
\hline $\begin{array}{l}\text { Want Insurance (2=believes useful, 1=like } \\
\text { to know details, 0=believes not useful }\end{array}$ & 1.024 & 1.027 & 1.778 & $0.963^{* *}$ \\
\hline $\begin{array}{l}\text { Self-eval re success } \\
\text { 3=v succ, 2=satisfac, 1=av succ, 0=unsucc }\end{array}$ & 1.786 & $1.474^{* *}$ & 1.667 & 1.577 \\
\hline Share of bus income in tot fam inc (in \%) & 58.514 & 65.608 & 85.000 & $61.553^{*}$ \\
\hline Has Business Training (1=Yes, 0=no) & 0.333 & $0.115^{* *}$ & 0.333 & 0.180 \\
\hline Seeks Consulting Advice (1=Yes, 0=no) & 0.643 & 0.628 & 0.889 & $0.613^{*}$ \\
\hline Reinvest bus surplus in bus(1=Yes, 0=no) & 0.214 & $0.423^{* *}$ & 0.667 & 0.748 \\
\hline
\end{tabular}

*t-test significantly different at $10 \%$; **significant at $5 \% . \mathrm{N}=120$

Source: Authors' calculations 


\section{Appendix A: Survey Questionnaire}

Translated from the original Spanish

Please, answer the following questions by making a check mark $(\mathrm{X})$ and fill in the blanks. Try to answer as much questions as possible. Leave in blank the questions you do not want to answer.

Date:

Full name:

Sex:

Age: (optional)

Time of business establishment: (years) (months)

1. Type of business by property

a) ___ Personal (business owner)

b) __ Agricultural Cooperative

c) __ Nonagricultural cooperative

d) ___ Family Business

e) Other

2. What kind of activity is the business in?

a) __ Paladar (restaurant)

b) __ Cafeteria

c) __ Landlord/lady housing

d) __ Transportation

e) ___ Agriculture

f) B_ Barbers and hairdressers

g) __ Other. What?

3. How many employees?

4. Your employees are...

a) Relatives

b) Individuals

5. Have you applied for a business bank loan in the last three years? Yes No

6. If "yes", provide credit conditions:

Term

Amount (specify currency)

Interest rate

Warranties:

Bank payment frequency:

7. If the answer to question 5 was that you did not make any request, state your reasons (you can check more than one):
a) __ I do not need credit because I have the necessary capital
b) __ The maximum loan amount granted by banks is not enough
c) I__ I do not know the procedures to apply
d) ___ Prefer not getting into debt
e) ___ I do not want to show my balances
f) __ I find it very troublesome
g) ___ Other.

8. How important are banks for your business? (Check only one):
a) __ Very important
b) __ Fairly important
c) ___ Of little importance
d) __ I do not make any operation with banks

9. Do you have a bank saving account? Yes No

10. How often do you make your saving deposit in the bank? (Check only one)

a)___ Weekly 

b) Monthly
c) __ Quarterly
d) Annual

Average amount in CUC?

11. Do you have savings out of the banks? Yes No

12. Would you like to have business insurance? (Check only one)

a) ___ it would be useful

b) ___ I would like to know the details to make a decision

c) I I do not think it is useful

d) I I do not know what it is

13. How successful is your business? (Check only one)

a) __ Very successful

b) Satisfactory

c) Regular

d) ___ No successful at all

Why?

14. How important (share) is your business income for the whole family income? (Check only one)
a) $10 \%$
b) $30 \%$
c) $50 \%$
d) $75 \%$
e) $100 \%$

15. What are the main barriers to your business growth? (Check, maximum, the most important three).
a) _ No
b) ___ Lack of inputs
c) ___ Lack of funding
d) ___ Little demand
e) H__ High taxes
f) ___ Excessive regulations
g) ___ Competition from other businesses
h) ___ Other. What?

16. What are the main sources of capital/financing for your business? (You can mark several).
f) ___ Own savings
g) Remittances
h) __ Bank loan
i) ___ loan from a friend
j) ___ family loan
$\mathrm{k})$ ___ The business is shared with someone not living in Cuba
1) ___ Other

17. What capital value you began the business with (CUC or its equivalent in another currency? (Check only one)
a)_Less than $300 \mathrm{CUC}$
b) Between 300 to $1000 \mathrm{CUC}$
c) ___ Between 1000 and 2000 CUC
d) ___ Between 2000 and 5000 CUC
e) B_ Between 5000 and 10000 CUC
f)___ more than $10000 \mathrm{CUC}$

18. If you have surplus in your business, how do you use it? (You can check more than one)
a) Business reinvestment
b) ___ House repairs investment
c) ___ Better nourishment for my family 
d) ___ Savings

e) Other. What?

19. Do you have received any training on business or business management?

Yes Where? No

On what were you trained?

20. Do you think your business has other similar business in competition?

Yes No

What?

21. Would you welcome specialized counseling in your business? Yes No

Kind of consultancy: 
Appendix B: Other answers given in response to Question 2: What kind of activity is the business in?

Disco Rental

Handicrafts

Videos and photographs

Butcher

Carpenter

Agricultural Products

Agricultural Products Peddler

Used Books

Transportation of agricultural products

Food Production

Construction

Flowers

Photography

Xerox copies

Gymnasium

Aluminum Foundry

Jewelry

Sports Instructor

Cosmetician

Carwash

Massage Therapist

Messenger service

Tailor/Stylist

Pianist

Tire Puncture Repair

Typist

English teacher

Shoe Retailer

Shoe Manufacturer

Children's Playhouse

Domestic Appliance Repair

Ornamental Plant Retail

Lathe workshop 